\title{
WRITING UP RESEARCH IN ENGLISH: CHOICE OR NECESSITY?
}

\section{ESCREVER A PESQUISA CIENTÍFICA EM INGLÊS: UMA QUESTÃO DE ESCOLHA OU NECESSIDADE?}

\author{
Sonia M.R.Vasconcelos*
}

In 2002, an editorial of The Annals of Thoracic Surgery ${ }^{1}$ stated that English was "a heavy burden" for a large number of researchers from non-native-English speaking (NNES) countries. This issue has recently been discussed in a Nature' Special Report entitled "Lost in Translation" 2 . The report addresses the difficulty NNES scientists have in mastering the English language. According to this report, a feeling of "frustration" permeates the career of some European scientists when it comes to doing and writing up research in English. The same appears to be true for Japanese and South Korean scientists.

In fact, for NNES authors, good command of English does not appear to be a minor issue in their doing of science. Also, although they are expected to master the four skills, there is no dispute that the writing skill has a unique place in their academic life. Particularly today, it can be argued that written English proficiency is a form of cultural capital in the scientific community. Accumulating it, or rather, the capital associated with it, confers power (and prestige) on its members ${ }^{3}$. Accordingly, the literature has reported that native-Englishspeaking (NES) researchers are at an advantage over NNES ones when it comes to getting published, especially in highimpact journals ${ }^{4}$. Concerning the writing of manuscripts, a study on the acceptance rate of cardiovascular research articles indicated that badly-written manuscripts (mostly from NNES authors) were more likely to be rejected than well-written ones ${ }^{5}$.

In fact, we could assume that common sense alone would tell us that writing well can boost the authors' chances of getting published. Even so, attention to language among scientists is still scant, which would account for the number of unreadable articles published even in top-tier journals. In a Letter published in the British Medical Journal ${ }^{6}$, the author reports that "over the past 20 years..." many articles have shown "that medical information (such as journal articles, informed consent forms) is written in an 'unreadable' writing style." Among the authors of such texts are NES researchers, as even those writing in their mother tongue can be poor writers. However, improving writing skills in the native language is not that difficult. As for a foreign language, a great deal of effort should be put into improving such skills.

With respect to English, sharpening communication skills to submit well-written manuscripts to international journals may be associated with academic survival. This is true if we consider that almost $97 \%$ of what is indexed in the Institute for Scientific Information Web of Knowledge (ISIThompson) database is in English ${ }^{7}$. Concerning Medline, $84 \%$ of all journals indexed in 2005 were in English, and $89 \%$ of citations in 2004 were to articles published in English ${ }^{8}$. A more recent study has suggested that "all the articles indexed in the Medline database will comprise only those written in the English language by 2014." ". It is therefore well worth the effort to develop scientific writing skills. As Benfield \& Howard state ${ }^{10}$, "scientific publishing and the use of English have become more international than ever before".

Nevertheless, focusing on English in this international scenario does not undermine the importance of writing for national publications. Meneghini \& Parker $^{11}$ have discussed the visibility of SciELO journals and argued that "they [journals] would benefit if articles from non-Englishspeaking authors were published in their original language and in English." Although the adoption of this policy would certainly pose a challenge to authors and editors, this initiative would possibly encourage Brazilian authors to improve their writing skills in English (even in Portuguese!).

Therefore, initiatives to tackle this language issue would be welcome. Particularly in Brazil, formal training in scientific writing in English is not part of academic culture, and the country's policy-makers appear to take English proficiency for granted in the development of science policies. What should authors do in this current situation? Perhaps, the first step to be taken is to reflect on the extent to which this language issue may affect research productivity. Does it affect yours? If so, the first decision to make is whether you want to wait for the implementation of scientist-friendly writing policies or use your initiative.

Waiting for the implementation of these policies may be an unwise decision. Firstly, because this is a process that should take time; secondly, because research funding (for writing projects, editorial services, etc) in Brazil is limited, and we cannot assume that all Brazilian researchers would benefit from such policies... For now, what Brazilian authors can possibly do is use their initiative and improve their English communication skills. As previously suggested, the accumulated capital associated with written English proficiency may contribute substantially to research visibility in this international scenario.

\footnotetext{
* S.M.R.Vasconcelos teaches scientific writing and is language editor of Annals of Magnetic Resonance. She has a Masters in English Literatures (Science \& Literature) and has conducted her doctoral research in the Science Education Program (PEGeD) of the Medical Biochemistry Institute (IBqM), Federal University of Rio de Janeiro (UFRJ).

Recebido em 28/01/07

Aceito para publicação em 16/02/07

Conflito de interesse: nenhum

Fonte de financiamento: nenhuma
} 


\section{REFERENCES}

1. Edmunds LH Jr. Writing in a borrowed tongue. Ann Thorac Surg. 2002; 73(1):15-6.

2. La Madeleine BL. Lost in translation. Nature. 2007; 445(25):454-5.

3. Bourdieu P. The forms of capital. In: Richardson JG, editor. Handbook of theory and research for the sociology of education. New York: Greenwood Press; 1986. p. 241-58.

4. Man JP, Weinkauf JG, Tsang M, Sin DD. Why do some countries publish more than others? An international comparison of research funding, English proficiency and publication output in highly ranked general medical journals. Eur J Epidemiol. 2004; 19(8):811-7.

5. Coates R, Sturgeon B, Bohannan J, Pasini E. Language and publication in "Cardiovascular Research" articles. Cardiovasc Res. 2002; 53(2):279-85.

6. Hochhauser M. Readability of British and American medical prose. Why are unreadable articles still being written [letter]? BMJ. 2003; 326(7391):711.

7. Jaffe S. No pardon for poor english in science. Scientist. 2003; 17(5):44.
8. Kotzin S. Journal selection for Medline. World Library and Information Congress: $71^{\text {th }}$ IFLA General Conference and Council "Libraries - A voyage of discovery." Available at: http:// www.ifla.org/IV/ifla71/papers/174e-Kotzin.pdf

9. Sousa Escandon MA, Gonzalez Guitian C, Gonzalez Fernandez MM.[Which language will MEDLINE speak in the next millennium?] Arch Esp Urol. 2000; 53(2):93-9.

10. Benfield JR, Howard KM. The language of science. Eur J Cardiothorac Surg. 2000; 18(6):642-8.

11. Meneghini R, Packer AL. Is there science beyond English? Initiatives to increase the quality and visibility of non-English publications might help to break down language barriers in scientific communication. EMBO Rep. 2007;8(2):112-6.

Como citar este artigo:

Vasconcelos SMR. Writing up research in English: choice or necessity? Rev Col Bras Cir. [periódico na Internet] 2007;34(1). Disponível em URL: http://www.scielo.br/rcbc

Endereço para correspondência:

Sonia M. R. Vasconcelos

Programa de Educação, Gestão e Difusão em Biociências (PEGeD) / Instituto de Bioquímica Médica (IBqM) / Bloco B / CCS / UFRJ. 